\title{
The impacts of social media on the \#EndSARs\# youth protests in Nigeria
}

\author{
Dickson Ajisafe ${ }^{1}$, Tinuade Adekunbi $\mathrm{Ojo}^{2}$ and Margaret Monyani ${ }^{3}$ \\ ${ }^{1}$ Department of Political Sciences (International Relations), University of Pretoria, South Africa. \\ ${ }^{2}$ Department of Political Science and International Relations, University of Johannesburg, South \\ Africa. \\ ${ }^{3}$ Department of International Relations, Wits University, South Africa.
}

\begin{abstract}
Since the emergence of ICT or digitalization in our contemporary world, especially in Africa, the use of social media as channels of communication has found expressions in political, economic, social, and business aspects of human dealings and engagements. This development calls for rigorous academic debate regarding the effectiveness of social media platforms as tools that citizens can use to influence government policies and decision making. The paper examines the likely outcomes of the protests regarding the change in government policy, reactions and proposed policies geared towards more regulation of social media and the implications on future social media. Drawing critical insights from the efforts of Nigerian youth on the strategic use of social media, this study engages secondary sources to understand and explain strategies and mechanisms to influence government policies and decision making via practical usage of ICT and social media in the age of digitalization. The paper concludes that the style of the \#EndSars protest may inspire other youth-led social media protests in other parts of the world. Questions also arise as to the nature and the character of the Nigerian state that led to the abrupt end of the protests.
\end{abstract}

\section{Introduction}

Since the innovative emergence of ICT or digitalization in the modern world, especially in Africa, the use of social media as channels of communication has found expressions in political, economic, social, and business aspects of human dealings and engagements. Social media has gained so much popularity amongst individuals due to the accessible means of self-expression and communication, especially Facebook, Twitter, WhatsApp, and Instagram [1]. This is because photos and videos allow others to glimpse into users' everyday lives,

${ }^{1}$ Corresponding author: ajisafedickson@yahoo.com 
interests, and personal stories. Without any misgivings, the use of social media has assisted social groups and movements and businesses to thrive in the dissemination of information and communication in the contemporary world; it has also influenced the dissemination of government communications, decisions, and policy making processes [2]. With respect to the Nigerian youth \#EndSARs\# protests, which were organized to peacefully protest against police brutality and call for comprehensive policy and policing reforms in the country, social media channels were maximized by the youth in Nigeria to herald their anti-police brutality protests that consequently influenced the Nigerian government decisions in its security and social policy making [2]. This development, therefore, calls for rigorous academic debate regarding the effectiveness of social media platforms as tools that citizens can maximize to influence government policies and decision-making processes in Africa and beyond.

Among other things, this paper aims at stimulating intelligent discussions regarding the instrumentality of Social Media in initiation, coordination and implementation of social mobilization towards influencing government policies and advocating for good governance. With specific reference to the Nigerian youth \#EndSARs\# peaceful protests, the study attempts to explore the capacity of citizenry in Africa, through the use of social media platforms, to agitate for social, economic, and political transformations within a polity in a peaceful manner. The paper is divided into five sections. The first section gives a brief background to the Nigerian youth peaceful \#EndSARs\# protests of police brutality and bad governance in Nigeria. The second section examines lessons learnt from the Nigerian youth usage of social media towards achieving \#EndSar\# protests' objectives. The third section investigates how the use of social media assisted the Nigerian youth in mobilizing themselves towards their \#EndSARs\# peaceful protests to the extent that it caught the attention of international communities. In other words, the section sheds more light on the influence of social media channel on \#EndSARs peaceful protests undertaken by the Nigerian youth and how this eventually attracted international solidarity. Gleaning from the Nigerian youth \#EndSARs\# peaceful protests, the fourth section of this study examines how social media could influence government policy making towards good governance across Africa. In this regard, the team investigates the uses of Social Media and agitations for good governance, Social Media restriction and security governance in Africa, as well as limitations of Social Media on policy changes and good governance on the continent. The concluding section of the paper touches on what could be done to maximize the effective use of social media towards good governance in Africa. Drawing critical insights from the efforts of the Nigerian youth on the strategic use of social media, this study engages secondary sources to comprehend, elucidate and analyze strategies and mechanisms to influence government policies and decision making via practical usage of ICT and social media platforms in the age of digitalization. It is assumed that the \#EndSARs\# protests' style may inspire copycat youth-led, social media-fueled and leaderless protests across Africa for the purposes of better governance and consequently usher in a productive type of non-violent protests in the region and beyond.

\section{The Nigerian youth \#EndSARs\# peaceful protests: A brief background}

The hashtag, '\#EndSARs\#', first appeared on Twitter in 2017. After that, the hashtag gradually and famously became a social movement in Nigeria. However, the social movement took momentum when a video went viral of SARs officials shooting a young man in a white SUV and stealing his car, leaving him dead on the road [3]. The social media reports of SARS abusing their power and victimizing citizens. The primary targets were the 
young and the rich in possession of iPhone, laptops, own cars, well dressed and possessed expensive things. People were violated, and privacy invaded. The SARS also invade taxpayer's privacy by checking individual's phones without their consent. Most citizens wake up daily with the fear of being harassed and victimized or probably get shot [2]. Although the government attempted to redress the SARS policy by disbanding and recognizing the unit multiple times and at the same time passing laws that will mitigate the inhumane activities and police brutality, yet the units' torture of the citizens, prevails [4].

The Nigerian \#EndSARs\# protests were led purely by the Nigerian youths without any formal leadership structure or mentoring but fully fuelled using social media. It is assumed that youths in Nigeria represent most of the population and are believed to be future generations [5]. Despite this, the future of Nigerian youth seems dark and uncertain. Meanwhile, there have been many reports on the role of SARs Police in intimidating and harassing every average Nigerian youth. Initially, the Special Anti-Robbery Squad (SARS) was a particular unit from the Nigerian Police Force established in 1992 to reduce the threats of armed robbers and reduce the rate of gun violence in the country. Although the goal was mainly achieved, the act has been conducted in inhumane ways. The social media reports of SARS abusing their power and victimizing citizens, most especially the youth and young professionals, were alarming. Even though the Nigerian Inspector General of Police further announced new policies and changes that would be implemented to reform SARS; nevertheless questions on proper implementation of measures highlighted are still being debated [6].

\section{The Nigerian youth \#EndSARs\# peaceful protests and international solidarity}

In the efforts to protest against police brutality in Nigeria, international celebrities were requested to address the Nigerian government to pay good attention to the agitation of the protesters [7]. International Musicians regarded as celebrities such as Seun Kuti, Boyce, DJ Switch, Saaki, Davido and other local celebrities were part of the movement. International stars such as Beyonce, Rihanna, John Boyen joined millions of people globally to stand in solidarity with Nigerian protesters and made their impact on social media on \#EndSARs\#. On October 21, due to the social media influence, the United Nations responded to the coldblooded killing of the innocent lives of Nigerian youth protesters killed by Nigerian Police and Army on October 20,2020. The U.N. Secretary-General called for the instant end to the police brutality and the unjust killing of Nigerian youths who are tired of the harassment and were protesting peacefully within their rights. The U.N. called on the Nigerian government to immediately put an end to this violent act. The statement was echoed by the U.S. elect president, Joe Biden, who gave a speech that the Nigerian president and Nigerian Army should end the brutality and work towards a more inclusive country that is sustainable for its citizens [7]. The profound act of using the online platforms to raise awareness of and call for the dissolution of the movement \#EndSars raised and captured the global imagination, which resulted in widespread protests that elicited a violent response from the Nigerian government. The Nigerian government's brutal response and the inhumane acts of violence on peaceful protesters and other unrelated groups who manipulated the objectives of the protests did not limit the strength of the protests. The \#EndSARs\# campaign revealed the in-depth and essential role social media can play in social movement, social mobilization, agitation for good governance, and respect for human rights in Africa [7]. Through various social media platforms, the \#EndSARs\# activists were able to reach out and organize massive movements calling out to thousands of Nigerians to action and holding Nigerian authorities to account, 
at the same time, catching the attention of the international communities in support for the \#EndSARs\# campaigns [8].

Furthermore, social media allowed financial supports to be raised to feed the protesters, pay for the hospital treatment of those wounded in the struggle and pay for the services of their defense lawyers. Social media was also used to enable lawyers to be called to go to court at short notice for protesters, coordinating logistics about upcoming protests in terms of timing and location [1]. Most importantly, social media was using real-time updates to keep people informed about what was happening. In these susceptible areas, Nigerian armed forces were stationed against the protesters [2].

\section{Social Media's impacts on \#EndSARs\# protests}

Since its inception in the 1990s, social media has marked a turning point in a communication network [9]. Billions of people all over the world are now digitalized and internet users. Even the developing economies have implemented different strategies to ensure that their societies are current with technological applications [4]. The current global pandemic, covid-19, further enabled the global economy to be more technologically compliant as people were forced to stay indoors, and the only means of communication was technology. As a result, social media in today's turbulent political environment has enabled previously disconnected and disadvantaged people to access communication networks. Social media has also encouraged people to share and exchange thoughts, perceptions, and ideas across global distances [10].

Social media, amongst other things, have also given people the opportunity to obtain information from individuals directly rather than relying on existing knowledge from a media organization. As the increase on the web 2.0 technology usage made global waves, the Nigerian community also experienced a massive surge in social media usage, which has benefited the different social movements witnessed in the past two years, including the \#EndSARs social training that gained global visibility [11]. Social movements have played an essential role over the decade in Nigeria. Social activities often initiated by a group of activists or anti-government actors are conducted to express grievances, interests, critiques, and proposed solutions on specific identified problems through collective actions $[4,9]$. Social movements historically involve these key actors leading and organizing the protests. However, social media has successfully replaced the pre-existing mobilization structures and has become a critical tool in organizing and coordinating social movements globally [11].

Social media does not only affect the mobilization of resources but also facilitates restructuring between social movements relationships. It also enabled the restructuring of public spheres and wholly changed communication and information flow in the society. This has led to a significant shift in the social network structures. Obaid [4] argued that there are two considerable influences of social media with regards to social movements. The first is that social media accelerates recruitment, mobilization, communication, and dissemination of information, expanding mobilization spaces not previously present in traditional mobilization techniques. It enables billions of people globally to communicate through Facebook, Twitter, Instagram, and other social media applications [10].

The social media network has also acted as a platform for different individuals, races, ethnic groups, and identities to share, build and collect emotions or feelings, which has led to a new type of virtual collective identity which social movements have capitulated upon for their protests [9]. Most significantly, social media has enabled the instant validation of information which overrides the system's media bias. This transformation has given social movements the ability to propagate a beneficial narrative and appeal to social sympathy. An example is the \#End SARs social movement [12]. Nigerians used the social media channel 
to express their feelings, disappointments and unhappiness at the poor government leadership and structural inequality in different regions. Most of the citizens were tired of the educational system, lack of basic infrastructure, unstable power supply (electricity), inadequate health care, bad roads, just to mention a few [13].

\section{Influence of Social Media on policy making and good governance in Africa}

Studies have shown that social media can function as a transformative agency for productive policymaking processes and good governance as well as an agency for socioeconomic and political development. According to a report by WeAreSocial (2019), it is reiterated that there has been not less than a 50 per cent increase in social media users in Africa since the period of its emergence on the continent till 2019 [15]. Indeed, social media has led to a drastic paradigm shift in the relations and communication engagement between governments and citizens, workers in private and public sectors, and multinational companies and their clients [14]. As such, the usages of the internet and social media platforms have become an integral part of private and public governance. As Asongu and Odhiambo [16] note, "social media continues to be useful in mobilizing and drawing citizens to focus on issues that are perceived as important and in priming public opinion among many Africans to get engaged in the political process of governance and democratization". Indeed, social media has become an essential conduit for reinforcing communication between the government and its citizenry. While acknowledging the importance of such transformation, it is necessary to note that there remains a gap in the maximization of social media to advocate for relevant and needed policy towards enhancing good governance in Africa.

\section{Limitations of Social Media and good governance in Africa}

The \#EndSARs\# protest draws our attention to the inability of social media platforms to completely overhaul ineffective governance structures to reflect and respond to the needs of the people. There are various reasons for this, but majorly, the inherent weak nature of African states [14]. Many African states, including Nigeria, are bedeviled with soft governance structures and other challenges that make it impossible to tap into the potential 7 of social media platforms. For governance founded and sustained by state-sanctioned violence, it is challenging for the leaders to allow for a 'bottom-up' source of governance ideas. In addition, proper usage of social media platforms needs the right backing with technically adaptive tools and models to allow for a productive flow of communication and information dissemination between the governments and their citizens. The technological info-structures in many African states are still at the infancy stage and, in some cases, nonexistent. This is despite the existence and the proliferation of social media platforms in the last decade. Technological capacity and infrastructure are critical in sieving essential opinions from the millions that are posted online daily. Even in some countries on the continent, such as South Africa, Nigeria, Kenya and Ghana, the impact of the already existing technological infrastructures remains a mirage at the grassroots level [16].

\section{Social Media restriction and security governance in Africa}

Studies have also shown the connection between social media and security $[16,17,18]$. This has consequently led to enacting restrictive regulations of social media usages by 
different governments in African states. There is a general fear among political leaders in Africa that social media platforms can be a conduit for security concerns. For instance, in July 2019, Chad lifted a 16-month social media ban based on security reasons. With African states being predominantly governed by leaders with authoritarian characters, there is a growing trend of framing social media as a security threat. Apart from Chad, other African countries such as Ethiopia, Uganda, Zimbabwe, Sudan, Tanzania, Togo, Burundi, Mali, and Guinea at different times, have regulated the use of social media in their countries and instituted social media shutdowns against the interest of their citizens using the Islamist terror attacks in Kenya as a precedent, where numbers of Islamist terror attacks are believed to have been orchestrated via social media platforms. The internet has made recruitment into terror organizations and the training elementary.

\section{Social Media restriction and the Nigerian government}

The recent development in Nigeria on the suspension of Twitter operations in the country serves as a relevant instance of how national governments in Africa react against and respond to the use of social media in policy and decision-making processes. On 5 June 2021, the Guardian news reported that the Federal Government of Nigeria has indefinitely suspended the microblogging and social networking service Twitter in the country [19]. According to this report, the Minister of Information and Culture, Lai Mohammed, claimed that the constant use of Twitter tends to undermine Nigeria's corporate existence. In addition, the Nigerian government also directed the National Broadcasting Commission (NBC) to commence the process of licencing all OTT and Social Media operations in the country [19]. As noted by the report, the conflict between the government of Nigeria and Twitter started in October 2020 after the co-founder of Twitter expressed his solidarity in support of \#EndSars\# youth protests against police brutality in Nigeria [19]. The Nigerian government assumes that Twitter, as an effective platform for communication and information dissemination, could be used to mobilize the Nigerian youth and other Nigerians against government policies and decision-making processes. However, this assumption would be wrong because Social Media, not excluding Twitter, could actually be maximized by the government of Nigeria to seek the opinions and advice of its citizens on good governance and how the country could move forward. The point is if the youth in Nigeria were able to maximize Social Media to successfully organize themselves and herald their concerns on the socio-economic and political zigzags of the Nigerian state, to the extent that the whole world consequently rallied around them in solidarity; then the government of Nigeria should understand that it has Social Media at its disposal to initiate and communicate relevant policies and programmes that would add values to its citizenry. It should be noted that the ban on the use of Twitter in Nigeria is a ban on the free speech platform of the people of the country as well as their right to freedom of speech in a democratic state.

\section{Social Media and agitations for good governance in Africa}

The question remains on how can the uses of social media influence policy making and good governance across Africa and beyond? Case studies such as the \#ThisFlag\# campaign's efforts to remove Robert Mugabe from power in Zimbabwe and the \#ZumaMustFall\# movement attempted to remove Jacob Zuma from office in South Africa. The \#EndSARs\# Nigerian peaceful youth protests police brutality and bad governance in Nigeria have all revealed that social media platforms possess the capacity to clamor for socio-economic and 
political agitations, be associated with political movements as well as agitate for political transformation and good governance. There is a consensus that such platforms provide a rich avenue to exchange information and organize demonstrations with a possibility of challenging political leadership. However, some authors have argued that social media platforms cannot mobilize changes since most of the users are mainly a few educated middle classes who support the status quo [1]. On the other hand, studying the Nigerian landscape, Orji [20] posits those social media platforms can be instrumental for political engagement. Similar observations have been made by Scholars [21], who observed that WhatsApp groups were very critical factors in the electoral process in Sierra Leone.

\section{Conclusion}

Gleaning from the Nigerian youth \#EndSARs\# protests, this study has advanced the debate on using social media in influencing government policies and agitating for good governance in Africa. Without any doubt, the style of the \#EndSARs\# protests of the Nigerian youth can stimulate youth-led, social media peaceful protests across Africa, which might introduce productive policy making processes and good governance on the African continent. The study has revealed the capacity that is embedded in citizens of Africa to initiate desired changes in the socio-economic and political developments of their nations through the use of social media platforms. In addition, the study has shown how ordinary individuals across African states can mobilize themselves in a peaceful manner to pressurize and assist their government for better governance. Meanwhile, the study also argues for a need to reconcile mainstream information outlets and social media platforms to effect and influence any meaningful policy change in Africa. The mainstream media outlets have been in existence for decades. Many Africans, especially those in cosmopolitan cities with the use of the internet, still heavily rely on them. This will strengthen protests for good governance and put more substantial pressure on African governments to effect relevant and needed socio-economic and political changes. In addition, while we applaud the role of media social protests, it is essential to note the proliferation of fake news sites whose aim is scaremongering. These platforms are prone to spreading misinformation which could lead to unnecessary protests. As mentioned earlier, models that filter content come to play a critical role in the separation of wheat from tares of information dissemination. Chonka [15], a specialist on Somali issues, warns that anarchy will bloom unless a clear distinction between mainstream and social environment is established. Chonka [15] points to this as a determining factor of the Somali political instability. The incoherence between mainstream and social media has resulted in an uncoordinated flow of communication among various critical political leaders and sectors. In addition to technical infrastructure, the African population needs to be equipped with technological and communication skills and knowledge that would enhance and advance social media usage towards government support, and if need be, towards peaceful protests for good governance purposes. This will play a significant role in mainstreaming what is appropriate regarding online content, moral values, and perceived threats to national security.

\section{References:}

1. Oginni, O.S. and Moitui, J.N. (2015). Social Media and Public Policy in Africa: Towards Enhanced Policy Process in Digital Age. Journal of Sustainable Development, 14(2), pp. 158-172. 
International Conference of Information Communication Technologies enhanced Social Sciences and Humanities 2021 - ICTeSSH 2021

2. Soladoye, A. A., \& Ojo, A. O. (2020). Impact of Social Media on Police Brutality Awareness in Nigeria. International Journal for Management and Modern Educational, 1(1) (2020), pp. 14-27.

3. Abbo, U., Njidda, B. A., \& Baba, A. (2020). Political strategies and social movements: A preliminary analysis of the failure of END SARS movement in Nigeria. International Journal of Intellectual Discourse, 3(2), pp 120-134.

4. Obaid, H. (2020). The Impact of Social Media on Social Movement and the Public Opinion Formation. Vist for Human Rights and Development. Available at https://vistointernational.org/publications/the-impact-of-social-media-on-socialmovements-and-public-opinion-formation/ (Accessed 03/04/2020).

5. Hattingh, S. (2020). The Hope of the \#EndSARS Protests. Green Left Weekly, (1288), pp.16-17.

6. Dambo, T. H., Ersoy, M., Auwal, A. M., Olorunsola, V. O., Olonode, A., Arikewuyo, A. O., \& Joseph, A. (2020). Nigeria's\# EndSARS movement and its implication on online protests in Africa's most populous country. Journal of Public Affairs, e2583.

7. Raimi, M. O., Okoyen, E., Tuebi, M., Raimi, A. A. G., Funmilayo, A. A., Oluwakemi, R. M., \& Joseph, B. O. (2021). Do Weak Institutions Prolong Crises? [\# ENDSARs] in the Light of the Challenges and opportunities beyond COVID-19 Pandemic and the Next Normal in Nigeria. Communication, Society and Media, 4(2), 1-19. ISSN, 2576-5388.

8. Iyorza, S., \& Nsa, B. (2020). Human Media and Behaviour Change Communication Trajectory of Calabar Youths of Cross River State in the EndSARS Excesses. Media \& Communication Currents, 4(2), pp. 171-190.

9. Cammerts, B. (2015). Social Media and Activism in Mansell, R., Hwa, P., The International Encyclopedia of Digital Communication and Society. Oxford, U.K.: Wiley-Blackwell, 2015, pp. 1027-1034.

10. Ohia, C., \& Salawu, M. M. (2020). COVID-19 pandemic and civil unrests in Africa: implication of recent\# EndSARS protests for increased community transmission in Nigeria. The Pan African Medical Journal, 37 (1), pp 47-55.

11. Ojedokun, U. A., Ogunleye, Y. O., \& Aderinto, A. A. (2021). Mass mobilization for police accountability: The case of Nigeria's\# EndSARS protest. They are policing: $A$ Journal of Policy and Practice, (2021), 1-11.

12. Olabamiji, O. \& Mariam, T. A. (2020). A Survey of the Impact of Endsars Protest on Small and Medium Enterprises (SMEs) In Oyo State, Nigeria. IOSR Journal of Business and Management (IOSR-JBM), 23(13), pp 1-6.

13. Adewole, M. A., and Osabuohien, E. S., (2007). "Analysis of Cost of Governance and Its Reduction Options in Nigeria", Nigerian Journal of Economic and Social Studies, 49(1), pp.137-159.

14. Jha, C.K., \& Kodila-Tedika, O., (2018), "Does Social Media Promote Democracy? Some Empirical Evidence", mimeo. Working Paper, wp/19/031. Centre de Recherche pour le Developpement Economique (CEREDEC) working paper.

15. Chonka, P. (2019). 'Igu sawir "gone too far"? Social media and state reconstruction in Somalia'. In T. Molony, \& M. Dwyer (Eds.), Social Media and Politics in Africa: Democracy, Censorship and Security Zed Books Ltd.

16. Asongu, S. and Odhiambo, N. (2018) "Governance and social media in African countries: an empirical investigation," Working Papers of the African Governance and Development Institute. 18/039, African Governance and Development Institute. Available at https://ideas.repec.org/p/agd/wpaper/18-039.html

17. Abor, J. Y., Amidu, Y., and Issahaku, H., (2018). "Mobile Telephony, Financial Inclusion and Inclusive Growth", Journal of African Business, 18(4), pp. 430-453. 
18. Jha, C.K., and Sarangi, S., (2017), "Does social media reduce corruption?" Information Economics and Policy, 39(June), pp. 60-71.

19. Erezi, D. (2021). Nigerian announces Twitter ban on Twitter. The Guardian. Retrieved from: Nigeria announces Twitter ban on Twitter - Nigeria - The Guardian Nigeria News - Nigeria and World News

20. Orji, I. J., Kusi-Sarpong, S., \& Gupta, H. (2020). The critical success factors of using social media for supply chain social sustainability in the freight logistics industry. International Journal of Production Research, 58(5), 1522-1539.

21. Riley, W. T., Oh, A., Aklin, W. M., \& Wolff-Hughes, D. L. (2019). National Institutes of Health support of digital health behavior research. Health Education \& Behavior, 46(2_suppl), 12S-19S. 